\title{
A PREVENÇÃO DOS RISCOS AMBIENTAIS NA INDÚSTRIA DO ABATE E PROCESSAMENTO DE CARNES E DERIVADOS: A SAÚDE COLETIVA E DOS TRABALHADORES.
}

\author{
PREVENTION OS ENVIRONMENTAL RISKS IN SLAUGHTER INDUSTRY AND \\ MEAT PROCESSING AND DERIVATIVES: A COLLECTIVE HEALTH AND \\ WORKERS.
}

\begin{abstract}
GUSTAVO ABRAHÃo dos SANTOS
Mestrando em Direito Ambiental pela Universidade Católica de Santos (ingressante em 2014 e concluinte em 2015). Pós-graduado em Direito Empresarial pela Universidade Católica de Santos (2008). Pós-graduado em Ética, Valores e Cidadania na Educação pela USP (2011/2012). Graduado em Direito pela Universidade Católica de Santos (1999). Professor de Direito na Faculdade do Guarujá UNIESP. Professor de ensino superior nos cursos de Administração, Contábeis e Gestão de Recursos Humanos da Faculdade Don Domênico. Professor convidado da Escola Superior de Advocacia - OAB/SP. Atuação acadêmica no Direito Tributário, Prática Jurídica Tributária, Direito Ambiental do Trabalho, Direito do Trabalho, Direito Difusos e Coletivos, Legislação Ambiental e Filosofia. Experiência de 10 (dez) anos nas atividades de docência. É Advogado militante a mais de 14 (quatorze) anos, com ênfase no Direito Ambiental do Trabalho, Direito Empresarial e Direito Tributário. gustavo.abrahao@hotmail.com

Norma SUELI PADILHA

Doutorado em Direitos Difusos e Coletivos pela Pontifícia Universidade Católica de São Paulo - PUC/SP (2004) e mestrado em Direito das Relacõos Sociais pela Pontifícia Universidade Católica de São Paulo - PUC/SP (2000). Pós-doutorado em Ética Ambiental pela UNICAMP (2010). Professor Associado da Universidade Federal do Mato Grosso do Sul - UFMS (graduação e pesquisa). Docente do Programa de Mestrado e Doutorado em Direito da Universidade Católica de Santos - Unisantos (pós-graduação e pesquisa). Atuação acadêmica na área de Direito Constitucional Ambiental, Meio Ambiente do Trabalho, Legislação Ambiental, Direito do Trabalho e Processo do Trabalho, Direitos Difusos e Coletivos e Tutela Processual Coletiva. Possui 13 orientações de mestrado concluídas , 4 livros publicados como autora única e 4 como co-autora. Possui experiência na Advocacia Pública (AGU) e na advocacia privada.

Autora da obra laureada com o Premio Jabuti 2011 na categoria direito: Fundamentos Constitucionais do Direito Ambiental Brasileiro. Membro da diretoria da APRODAB - Associação dos Professores de Direito Ambiental no Brasil. Palestrante e conferencista. Professora colaboradora da Escola Nacional de Formação e Aperfeiçoamento de Magistrados do Trabalho - ENAMAT. normasp@uol.com.br
\end{abstract}

\begin{abstract}
RESUMO
A indústria de abate de carnes e derivados produz um grave risco de contaminação do meio ambiente, da saúde coletiva e dos trabalhadores, por meio de suas externalidades negativas. Neste contexto, o artigo analisa os instrumentos jurídicos de prevenção dos riscos ambientais no abate de carnes em matadouros, especialmente do licenciamento ambiental, e destaca a incidência da clandestinidade e da ineficiência da fiscalização como elementos potencializadores do risco à qualidade ambiental. Destaca, ainda, os riscos da atividade que afetam diretamente a saúde dos trabalhadores e os instrumentos de proteção decorrentes do direito ambiental do trabalho. E preconiza a necessidade do cumprimento das normas ambientais e a eficiência de sua fiscalização como elementos essenciais a sustentabilidade ambiental, social e econômica da atividade.
\end{abstract}

Palavras-chave: indústria abate carnes e derivados; contaminação ambiental; risco ambiental; saúde coletiva, Trabalhadores, ambiente laboral.

\begin{abstract}
The slaughter of meat and meat industry produces a serious environmental contamination risk, public health and workers, through their negative externalities. In this context, the article analyzes the legal instruments for the prevention of environmental risks in the meat slaughter in slaughterhouses, especially the environmental licensing, and highlights the incidence of secrecy and surveillance inefficiency as enhancers elements of risk to environmental quality. Also highlights the risks of the activity that directly affect the health of workers and the protection of instruments falling under the environmental labor law. AND It calls for the need of compliance with environmental standards and the efficiency of its supervision as essential environmental sustainability, social and economic activity.
\end{abstract}

Keywords: slaughter industry meat and meat products; environmental contamination; environmental risk; public health, workers, workplace 


\section{SUMÁRIO}

INTRODUÇAO; 1 OS RISCOS AMBIENTAIS NO ABATE E PROCESSAMENTO DE CARNES E DERIVADOS; 2 A PREVENÇÃO AOS RISCOS AMBIENTAIS POR MEIO DE LICENÇA AMBIENTAL E SELO DE INSPEÇÃO DO MINISTÉRIO DA AGRICULTURA 3 RISCO AO AMBIENTE LABORAL E A SAÚDE DOS TRABALHADORES CONCLUSÃO; REFERÊNCIAS.

\section{INTRODUÇÃO}

A industrialização brasileira de produção de carne compreende parte considerável da indústria de alimentos, sendo que para a obtenção de sua matéria prima, o processo de abate dos animais, bem como o processamento de derivados é etapa crucial e que exige o cumprimento de regras sanitárias e de saúde coletiva, tendo em vista o alto grau de riscos de contaminação ambiental que envolve os abatedouros de animais, expondo a riscos a qualidade ambiental, a saúde coletiva da população, bem como, a saúde dos trabalhadores no ambiente laboral.

Evidenciando o perigo dos riscos ambientais no processo de abate de carnes para alimentar o alto consumo nacional e a crescente indústria exportadora de carne, o presente artigo analisa, no contexto da expansão das atividades agroindustriais no país, a preocupação com a elevada exposição de risco de contaminação ao meio ambiente, a saúde coletiva e, mais especificamente, ao trabalhador, decorrente da alta produção de resíduos tóxicos pelos abatedouros de animais no País, por meio de suas externalidades negativas, quais sejam, os resíduos sólidos e líquidos decorrentes do processo de abate de animais, e que no contexto brasileiro agrava-se pela dimensão da ineficiência na fiscalização das normas regulamentadores, bem como pela ocorrência de indústrias clandestinas no setor de produção de abate e processamento de carne, que sinaliza a importância das medidas de prevenção que garantam a proteção da saúde coletiva, e a eficiência da fiscalização pelos órgãos governamentais competentes, para garantia da qualidade ambiental do produto, dos consumidores, e do meio ambiente laboral.

A falta de inspeção, a grande territorialidade do país e as irregularidades no corte produção da indústria do abate irregular potencializam os riscos de contaminação ambiental e 
ISSN 1981-3694

(DOI): 10.5902/1981369418921

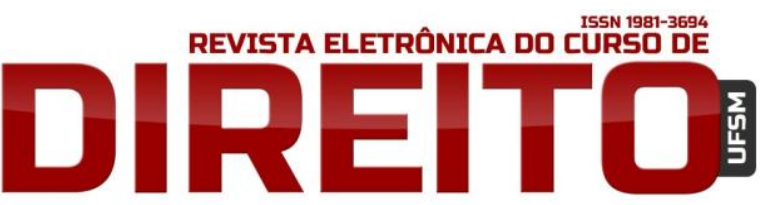

A PREVENÇÃO DOS RISCOS AMBIENTAIS PROVENIENTES DO ABATE E PROCESSAMENTO DE CARNES E DERIVADOS: A SAÚDE COLETIVA

E DOS TRABALHADORES

denotam a essencialidade de um eficiente controle da produção e da implementação do princípio da prevenção em prol da saúde coletiva e dos trabalhadores.

Neste contexto, tornam-se imprescindíveis a análise dos impactos ambientais e a concessão da licença ambiental para o abate e processamento de carnes e derivados, por meio do processo de licenciamento ambiental, a fim de se garantir a qualidade da produção e eliminar riscos de contaminação, impondo sobre os métodos da produção, por meio das licenças ambientais, as medidas necessárias para a prevenção ambiental e o bem estar animal.

A clandestinidade na atividade de abate de carnes no País é um contexto preocupante que superdimensiona os riscos de contaminação do meio ambiente, da saúde e coletiva e dos trabalhadores do setor, que na verdade, são a primeira coletividade a sofrer os danos pela exposição aos agentes contaminantes no ambiente laboral.

Neste contexto, o artigo apresenta um alerta para os riscos de contaminação ambiental, da saúde coletiva e laboral, decorrentes do processo de abate de animais, uma atividade que de deve estar totalmente submetida aos instrumentos de controle do poder de policia, sem descuidar da aplicação do principio da prevenção, e de seus instrumentos jurídicos para garantia da qualidade ambiental.

\section{OS RISCOS AMBIENTAIS NO ABATE E PROCESSAMENTO DE CARNES E DERIVADOS}

O Brasil possui uma extensão territorial abrangente que beneficia ao agronegócio, e mais, particularmente, ao setor pecuário da economia.

$\mathrm{Na}$ indústria de abate estão incluídos os estabelecimentos que realizam o abate de bovinos, suínos, equinos, aves, entre outros, e/ou industrializam a carne sob a forma de produtos para posterior processamento, exportação ou venda direta aos consumidores nacionais.

Segundo o Ministério da Agricultura, por meio do Regulamento da inspeção industrial e sanitária de produtos de origem animal:

o matadouro ou abatedouro é um estabelecimento dotado de instalação adequada para a matança de quaisquer das espécies de açougue, visando o fornecimento de carne "in natura" ao comércio interno, com ou sem dependências para a industrialização; disporá obrigatoriamente, de instalação e 
ISSN 1981-3694

(DOI): $10.5902 / 1981369418921$

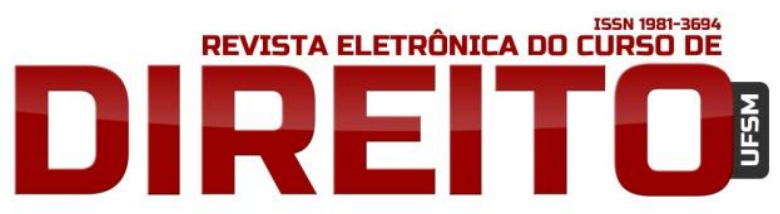

A PREVENÇÃO DOS RISCOS AMBIENTAIS PROVENIENTES DO ABATE E PROCESSAMENTO DE CARNES E DERIVADOS: A SAÚDE COLETIVA

E DOS TRABALHADORES

GustaVo ABRAHÃO dOS SANTOS, NORMA SUELI PADILHA

aparelhagem para o aproveitamento completo e perfeito de todas as matériasprimas e preparo de subprodutos não comestíveis ${ }^{1}$.

A atividade do abate de animais é relevante no país, considerando que a Revista Nacional da Carne, tendo como base a Associação Brasileira da Indústria Exportadora de Carne (Abiec) indica que: "100 anos após embarcar a exportação de carne, o Brasil tem mais motivos para celebrar além do centenário da atividade. O faturamento recorde de US\$ 7,2 milhões previsto para 2014 e as expectativas ainda mais otimistas para 2015 são algumas delas"2.

Segundo a Revista Nacional da Carne: "as exportações entre janeiro a novembro superam os resultados do ano passado. Nos onze meses de 2014 , o faturamento foi de US\$ 6,5 bilhões, representando um aumento de 8,16\% em relação ao mesmo período de 2013"3.

A grande quantidade de produção de abate e processamento de carnes sinaliza atenção a prevenção da saúde coletiva, tendo em vista que quanto maior a quantidade, maior é a demanda pela fiscalização por órgãos competentes do governo, e assim, na falta de inspeção, poderão ser maiores os riscos ambientais aplicados a esta atividade econômica.

Neste ponto, a estrutura especializada na industrialização de abates e processamento de carnes e derivados é necessária, considerando que a fiscalização desta produção é essencial para a saúde coletiva dos consumidores no exterior e no Brasil, ainda mais que, segundo a Revista Nacional da Carne, "neste ano, o número de abate deve chegar a 43,9 milhões. Aproximadamente $20 \%$ da carne produzida no Brasil é exportada"4.

Neste sentido, afirma N. Alencar:

a produção animal para corte no Brasil é uma atividade econômica de grande relevância que se traduz no surgimento de um número crescente de abatedouros, seja de suínos, bovinos ou de aves. Mesmo sendo considerado um grande produtor de carne, o Brasil enfrenta grandes problemas em relação à inspeção no abate $^{5}$.

\footnotetext{
${ }^{1}$ BRASIL. Ministério da Agricultura. Decreto $\mathrm{n}^{\circ}$ 30.691de 29/03/1952. Dispõe sobre o Regulamento da inspeção industrial e sanitária de produtos de origem anima e dá outras providências. In: Diário Oficial da República Federativa do Brasil, Brasília, DF, 7 jul. 1952. Disponível em: < http://www.planalto.gov.br/ccivil_03/decreto/1950-1969/D30691.htm> Acesso em: 13 jul. 2015.

2 REVISTA NACIONAL DA CARNE. Disponível em: <http://nacionaldacarne.com.br/apos-novo-recordeexportacoes-de-bovino-miram-alta-de-11-em-2015/> Acesso em: 09 ou. 2015.

${ }^{3}$ Apud. REVISTA NACIONAL DA CARNE.

${ }_{5}^{4}$ Apud. REVISA NACIONAL DA CARNE.

5 ALENCAR, N. (2002) Abatedouros de Bovinos e suínos. CTP - Revista Tecnologia e Treinamento Agropecuário. Disponível em: <http://www.cpt.com.br/revista/mattec/0165.asp> Acesso em: 02 jul. 2015.
} 
ISSN 1981-3694

(DOI): $10.5902 / 1981369418921$

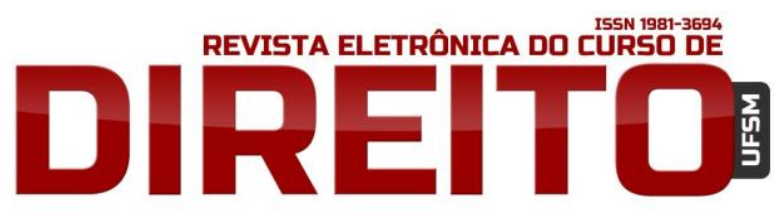

A PREVENÇ̃̃O DOS RISCOS AMBIENTAIS PROVENIENTES DO ABATE E PROCESSAMENTO DE CARNES E DERIVADOS: A SAÚDE COLETIVA

E DOS TRABALHADORES

GustaVo ABRAHÃO dOS SANTOS, NORMA SUELI PADILHA

Neste contexto, relevam de importância as condições sanitárias e ambientais do processo de abate dos animais para o processamento da carne. Entretanto, um dos graves riscos que envolvem as atividades econômicas de abates e processamento de carnes e derivados no país ocorre pela falta de inspeção e irregularidades na qualidade da produção, podendo ocasionar sérios riscos ambientais a saúde coletiva humana.

De acordo com Maria Zelia Rouquayrol e Naomar de Almeida Filho, "a maior parte dos municípios brasileiros não desenvolve ações de inspeção dos produtos de origem animal, nem dispõe de condições adequadas de abate" ${ }^{\text {. }}$.

Considerando que os abatedouros produzem resíduos sólidos e líquidos que são gerados nas diversas etapas do processo industrial, é muito importante a questão da limpeza e higienização das instalações e equipamentos, que constituem, pela sua composição, fontes de poluição e contaminação, propiciando ameaças constantes ao consumo humano no que se refere à saúde coletiva.

Argumenta Eneo Alves da Silva Junior que:

os alimentos de origem animal consumidos pelo homem, podem ser contaminados por micro-organismos patogênicos durante qualquer uma das etapas de produção, manipulação, armazenamento, distribuição e transporte, ressaltando que, além do risco atribuído ao processo de industrialização, as precárias condições físicas dos locais de abate dos animais e a falta de fiscalização da comercialização dos produtos podem afetar ainda mais a qualidade destes alimentos ${ }^{7}$.

Neste sentido, Ministério da Agricultura Pecuária e Abastecimento alerta que "o risco maior é a toxinfecção alimentar, que pode levar à morte. Mas existem outras doenças que são transmitidas dos animais aos seres humanos"8.

A falta de inspeção, a grande territorialidade do país e as irregularidades no corte produção da indústria do abate irregular impulsionam os riscos ambientais a serem compelidos pelo controle da produção, sendo esta a prevenção ambiental a saúde coletiva.

A prevenção ambiental, segundo Édis Milare:

O principio da prevenção é basilar o Direito Ambiental, concernindo à prioridade de que devem ser dadas as medidas que evitem o nascimento de atentados ao

\footnotetext{
${ }^{6}$ ROUQUAYROL, Maria Zelia; ALMEIDA FILHO, Naomar de. Epidemiologia e saúde. 6.ed. Rio de Janeiro: Medsi, 2003., p. 499-513.

7 SILVA JR, Eneo Alves. Manual de controle higiênico-sanitário em Alimentos. São Paulo: Livraria Varela, 2002, p. 177.

${ }_{8}$ BRASIL. Ministério da Agricultura, Pecuária e Abastecimento (MAPA). disponível em: <http://www.agricultura.gov.br/animal/noticias/2013/02/mapa-alerta-para-os-perigos-do-consumo-decarne-sem-fiscalizacao> Acesso em: 09 out.2015.
} 
ambiente, molde a reduzir ou eliminar as causas de ações suscetíveis de alterar a sua qualidade?

Neste passo, a prevenção ambiental no caso da indústria do abate ocorre de duas maneiras: controle por meio da inspeção do Ministério da Agricultura e controle por meio do Ministério do Meio ambiente, através das Resoluções CONAMA que tratam do processo de licenciamento ambiental.

Bem define Paulo de Bessa Antunes, que o princípio da prevenção "aplica-se a impactos ambientais já conhecidos e dos quais se possa, com segurança, estabelecer um conjunto de nexos de causalidade que seja suficiente para identificação de impactos futuros" ${ }^{10}$.

Portanto, imprescindível a análise dos impactos ambientais e a concessão da licença ambiental para o abate e processamento de carnes e derivados, e posterior, processo de licenciamento ambiental, como instrumentos necessários a prevenção ambiental, antes mesmo do Selo de Inspeção Federal do Ministério da Agricultura (SIF).

\section{A PREVENÇÃO AOS RISCOS AMBIENTAIS POR MEIO DE LICENÇA AMBIENTAL E SELO DE INSPEÇÃO DO MINISTÉRIO DA AGRICULTURA.}

Os abatedouros de animais são atividades econômicas que podem causar sérios danos a saúde coletiva, e, portanto submetida a imprescindibilidade do licenciamento ambiental, consoante as regras estabelecidas no artigo 225 , parágrafo $1^{\circ}$, Inciso IV da Carta Magna. A indústria de abate é uma atividade efetiva e potencialmente poluidora cujos riscos impactos ambientais devem ser analisados por meio do Estudo de Impacto Ambiental dentro do processo de licenciamento ambiental perante a autoridade competente, por meio do qual se controla a imposição das ações preventivas e/ou medidas compensatórias necessárias para a operação adequada da atividade.

Conforme Ronaldo Rocha Maria, "os problemas ambientais gerados pela atividade de frigoríficos e abatedouros estão relacionados com os seus despejos ou resíduos oriundos de diversas etapas do processamento industrial"11.

\footnotetext{
${ }^{9}$ MILARÉ, Edis. Direito do Ambiente : doutrina, pratica, jurisprudência, glossário / Edis Milaré. - 2. ed. rev. atual. e ampl. - São Paulo : Editora Revista dos Tribunais,2001.

${ }^{10}$ ANTUNES, Paulo de Bessa. Direito Ambiental. 11. ed. Rio de Janeiro: Lumen Juris Editora, 2008.

11 ROCHA MARIA, Ronaldo. Avaliação da eficiência no tratamento de efluentes líquidos em frigoríficos.In: Trabalho de Conclusão de Curso, apresentado à banca examinadora da Faculdade Dinâmica das Cataratas -
} 
ISSN 1981-3694

(DOI): $10.5902 / 1981369418921$

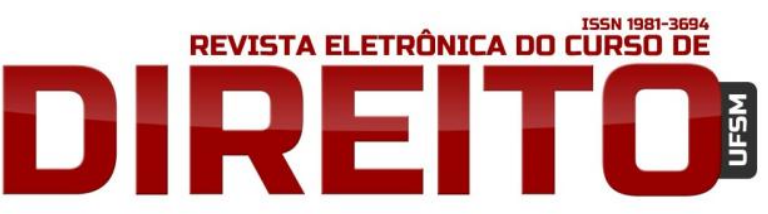

A PREVENÇ̃̃O DOS RISCOS AMBIENTAIS PROVENIENTES DO ABATE E PROCESSAMENTO DE CARNES E DERIVADOS: A SAÚDE COLETIVA E DOS TRABALHADORES

GustaVo ABRAHÃO dOS SANTOS, NORMA SUELI PADILHA

0 processo de abate de animais é de alto risco de contaminação, pois gera uma quantidade considerável de resíduos contaminantes, afinal trata-se de morte de seres vivos, e geralmente concentrados em grande quantidade em pequenos espaços, nos grandes matadouros do País. Um documento do Banco do Nordeste relata no Manual de Impactos Ambientais ${ }^{12}$ que:

0 processo operacional nos matadouros de pequeno porte compõe-se das seguintes etapas: espera nos currais, abate, eliminação do sangue, separação de pele (gado), eliminação de pelos (ovinos) destripamento e preparação par ao comércio. Nos grandes matadouros ocorre uma maior concentração dos animais em currais de espera, acarretando a geração de resíduos (fezes) em grande quantidade. A limpeza dos animais também gera uma grande quantidade de águas residuárias (lavagem) contendo concentração de resíduos sólidos e líquidos que necessitam de tratamento e disposição final.

Uma relevante questão com relação aos resíduos produzidos pelos abatedouros de animais são as contaminações que podem afetar o meio ambiente, atingindo o solo, subsolo e água, e por consequência a saúde humana. Neste sentido o controle dos resíduos é essencial para a manutenção da qualidade ambiental.

Segundo Banco do Nordeste, no Manual de Impactos Ambientais, "os principais impactos ambientais negativos nos abatedouros são: a geração de efluentes hídricos que podem provocar a contaminação dos solos e das águas superficiais e subterrâneas, além de gerar odor indesejado na decomposição da matéria orgânica"13.

E assim, pensa Ronaldo Rocha Maria que:

Embora a preocupação com o tratamento dos efluentes gerados pela atividade de abatedouros, não seja uma novidade, a descrição da eficiência dos processos utilizados e os cuidados com novas técnicas de tratamento, são de interesse não só dos abatedouros, mas também dos órgãos governamentais envolvidos, com a qualidade do meio ambiente, necessárias para desenvolver esta atividade econômica essencial, tomando os devidos cuidados com os resíduos gerados ${ }^{14}$.

Por outro lado, quanto ao processamento da carne e derivados, relata o Banco do Nordeste, no Manual de Impactos Ambientais que:

As unidades processadoras de carnes trabalham com as peças provenientes de matadouros, para a produção de carnes cozidas, curadas (secas), defumadas e enlatadas, embutidos, carne fatiada congelada ou fresca, tripas para lingüiça, entre outros. As linhas de processamento de carne mais comuns são: i) corte de carne para atendimento de setores de consumo direto (restaurantes, hot[eis,

UDC, como requisito parcial para obtenção de grau de Engenharia Ambiental. Prof. Orientador: Edneia Santos de Oliveira Lourenço. UDC. Foz do Iguaçu, 2008, p. 15.

${ }^{12}$ BNB. BANCO DO NORDESTE. Manual de Impactos Ambientais. Coord. Ademir Costa 1. ed. .Fortaleza: Banco do Nordeste, 1999. p.49

${ }^{13}$ BNB. Banco do Nordeste. Apud.,p.49.

${ }^{14}$ ROCHA MARIA, Ronaldo. Apud., p. 15-16. 
ISSN 1981-3694

(DOI): $10.5902 / 1981369418921$

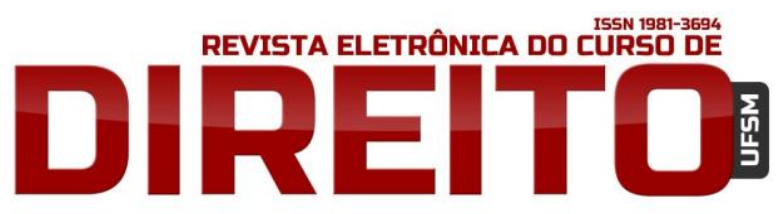

A PREVENÇÃO DOS RISCOS AMBIENTAIS PROVENIENTES DO ABATE E PROCESSAMENTO DE CARNES E DERIVADOS: A SAÚDE COLETIVA

E DOS TRABALHADORES

GustaVo ABRAHÃO dOS SANTOS, NORMA SUELI PADILHA

etc); ii) produção de presentu e defumados ou enlatados; iii) produção de embutidos salsichas, mortadelas, fiambre, etc); iv produção de lingüiça e de charque. Os principais impactos ambientais negativos que podem ser gerados nas plantas de processamento de carne são decorrentes da produção de: i) áugas residuárias; ii) gases de escape/saída de ar; iii) ruído; iv) desperdícios; v) calor resídua; vi) resíduos sólidos.

No anexo da Resolução CONAMA n. 237/97, existe uma lista de atividades que dependem de licenciamento ambiental, entre elas, estão os abatedouros de animais e a indústria de processamento de carnes, listadas no item "Indústria de produtos alimentares e bebidas, como matadouros, abatedouros, frigoríficos, charqueadas e derivados de origem animal" 15 .

Portanto, os abatedouros de animais se submetem a concessão das licenças ambientaisl nos termos do art. 80 da Resolução CONAMA n. 237/97, sendo elas: Licença Prévia (LP); Licença Instalação (LI); e Licença de Operação (LO).

Neste sentido Terence Dornelles Trennepohl afirma que: "essas licenças têm como finalidade aferir a regularidade do empreendimento diante da legislação ambiental"16.

Segundo Andreas Joachim Krell, "em verdade, o que a resolução n. 237/97 tentou fazer, foi estabelecer um sistema nacional de divisão das atribuições de atividades de licenciamento entre as esferas federativas, buscando evitar duplicidades de procedimentos"17.

Neste passo, os abatedouros de grande porte são fiscalizados pela Secretaria Estadual do Meio Ambiente desde que a atividade envolva mais de um município, existindo impactos ambientais regionais, segundo o artigo $5^{\circ}$ da Resolução CONAMA n. 237/97, ou pela Secretaria Municipal do Meio Ambiente SEMMA, havendo impactos ambientais perante o município, conforme o artigo $6^{\circ}$ da Resolução CONAMA 237/97.

E mais, a Resolução CONAMA 385/2006 estabelece procedimentos a serem adotados para o licenciamento ambiental de agroindústrias de pequeno porte e baixo potencial de impacto ambiental. Nesta Resolução CONAMA, define-se abatedouros de pequeno porte, como

\footnotetext{
${ }^{15}$ BRASIL. Resolução do Conselho Nacional do Meio ambiente (CONAMA) 237/97. Dispõe sobre a revisão e complementação dos procedimentos e critérios utilizados para o licenciamento ambiental In: Diário Oficial da República Federativa do Brasil, Brasília, DF, 22 dez. 1997. Disponível em: <http://www.mma.gov.br/port/conama/legislacao/CONAMA_RES_CONS_1997_237.pdf> Acesso em 13 jul. 2015.

${ }^{16}$ TRENNEPOHL, Terence Dornelles. Fundamentos de Direito Ambiental. 2a edição, Editora Podvim, 2007, p. 95.

17 KRELL, Andreas Joachim."O licenciamento ambiental no SISNAMA: Competência e controle" Paisagem, Natureza e Direito. BENJAMIN, Anotnio Herman (Org.) São Paulo: Instituto O direito por um Planeta Verde,2005, Vol. 1, p. 167.
} 
ISSN 1981-3694

(DOI): $10.5902 / 1981369418921$

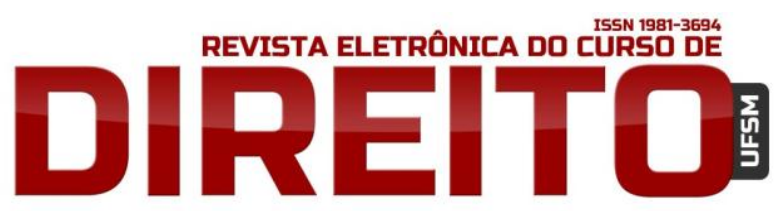

A PREVENÇÃO DOS RISCOS AMBIENTAIS PROVENIENTES DO ABATE E PROCESSAMENTO DE CARNES E DERIVADOS: A SAÚDE COLETIVA

E DOS TRABALHADORES

GustaVo ABRAHÃO dOS SANTOS, NORMA SUELI PADILHA

sendo: "os abatedouros que não deverão ultrapassar a seguinte capacidade máxima diária de abate de animais de grande porte: até 03 animais/dia; animais de médio porte: até 10 animais/dia; animais de pequeno porte: até 500 animais/dia”18.

Para a concessão da licença ambiental, o empreendedor deverá providenciar o Estudo Prévio de Impacto Ambiental, bem como identificar se a atividade econômica é de grande, médio ou pequeno porte, a modalidade de licença ambiental pretendida, informações sobre zoneamento ambiental, qual seja, se na zona rural ou urbana, a vizinhança do entorno desta atividade, as fontes de abastecimento de água e as finalidades que serão supridas no abatedouro, bem como os efluentes líquidos e seus despejos, informações sobre o processo de produção e os riscos ambientais da atividade, listar os equipamentos utilizados na atividade, bem como a mão de obra utilizada nesta atividade, e ainda, o tratamento dos resíduos sólidos e o confinamento para a destinação final.

Entretanto, embora não se discuta a imprescindibilidade do licenciamento ambiental para tal atividade, o que comumente ocorre no País, é que a produção e métodos de abate e processamento de carnes e derivados, possui um grande incidência de clandestinidade, o que potencializa e superdimensiona os riscos de contaminação ao meio ambiente e a riscos a saúde coletiva e do ambiente laboral.

Abatedouros clandestinos são aqueles que não possuem licença ambiental, portanto, descumprem a Resolução CONAMA n. 237/97 e a Resolução CONAMA n. 385/2006, e atuam sem nenhum controle sobre os ambientais e à saúde humana. Colocando em evidência o quanto o exercício ilegal desta atividade coloca em risco a sadia qualidade de vida de todos.

Neste contexto de alto risco e para exemplificar a gravidade da clandestinidade de tal atividade no País, Silvia Cordeiro, comenta um caso concreto que se mostra adequado para a contextualização do tema apresentado. Trata-se de um caso de clandestinidade da atividade de abate de animais que por meio do abatedouro municipal de Ponta Grossa/PR, que atuava sem licença ambiental e sequer licença sanitária, além de estar localizado em área de preservação permanente, e cuja interdição foi requerida pelo Ministério Público do Paraná, por meio de Ação Civil Pública, na qual o Município também foi incluído no polo passivo por ausência do dever de fiscalização:

\footnotetext{
${ }^{18}$ BRASIL. Resolução do Conselho Nacional do Meio ambiente (CONAMA) 385/06. Estabelece procedimentos a serem adotados para o licenciamento ambiental de agroindústrias de pequeno porte e baixo potencial de impacto ambiental. In: Diário Oficial da República Federativa do Brasil, Brasília, DF, 29 dez. 2006. Disponível em <http://www.mma.gov.br/port/conama/legiabre.cfm?codlegi=523> Acesso em 13 jul. 2015.
} 
O Ministério Público do Paraná (MP-PR) pediu a justiça, a interdição imediata e o fechamento de um abatedouro de animais municipal da Prefeitura de Ponta Grossa/PR. (...) Segundo o MP, o local está em "precárias condições ambientais e sanitárias, que promovem intensa atividade poluidora”. A ação civil pública foi ajuizada contra a Associação do Comércio e Indústria de Carnes Ponta Grossa (AcicPG), que administra o local, e também, contra o município, que é a dona do terreno e deveria fiscalizar o trabalho (...). O MP alega que o "Matadouro Municipal nunca obteve a competente licença de operação, documento indispensável para o funcionamento". Além disso, o Ministério Público ainda cita que o abatedouro não possui uma licença sanitária e está localizado em Área de Preservação Permanente (APP). Segundo o MP, as condições contrariam a legislação ambiental, o Código do Consumidor e as normas de saúde pública ${ }^{19}$.

A clandestinidade na atividade de abate de animais para consumo é altamente é altamente preocupante quanto a dimensão dos riscos de contaminação, pois além de expor gravemente o meio ambiente, a qualidade da carne distribuída coloca em risco a saúde coletiva dos consumidores.

Além do licenciamento ambiental outro controle imprescindível para a qualidade da produção na indústria de abate é Selo de Inspeção Federal do Ministério da Agricultura (SIF), Segundo o Ministério da Agricultura Pecuária e Abastecimento ${ }^{20}$ :

O SIF tem o controle da origem dos produtos. Cada animal abatido é fiscalizado por uma equipe do Mapa, composta por veterinários e auxiliares, além de profissionais contratados pela própria empresa. Em caso de detecção de irregularidades no procedimento de colocação do SIF, o processo de produção é interrompido, há a autuação do estabelecimento e a avaliação do risco para a produção. 0 processo só é retomado quando a empresa apresentar um plano de prevenção

Neste passo, os abatedouros que não estiverem cadastros no Ministério da Agricultura, haverão de comercializar carnes e processamento de derivados com riscos ambientais aos consumidores no que se refere a saúde coletiva humana.

O controle da atividade inclui um procedimento a ser cumprido diante do Ministério da Agricultura quanto a produção e comercialização na indústria do abete no Brasil.

Preconiza o Ministério da Agricultura Pecuária e abastecimento ${ }^{21}$ que:

19 CORDEIRO, Silvia. MP-PR pede interdição e fechamento do abatedouro de Ponta Grossa. Ação civil pública foi ajuizada contra município e administradora do local. Matadouro está em "condições ambientais e sanitárias precárias", alega MP. G1, globo, Paraná. Disponível em: <http://g1.globo.com/pr/campos-geraissul/noticia/2013/10/mp-pr-pede-interdicao-e-fechamento-do-abatedouro-de-ponta-grossa.html> Acesso em: 13 de jul. 2015.

${ }^{20}$ Apud. MAPA, 2015. 
As vistorias nesses estabelecimentos são diárias e já começam antes do início da produção. Dados do Departamento de Inspeção de Produtos de Origem Animal (Dipoa) apontam para 278 os abatedouros sifados no País. No ano passado, os processos produtivos de produtos de origem animal apresentaram elevados índices de conformidade $(90,51 \%)$. No período, foram analisadas 75.020 amostras de produtos de origem animal, sendo que $94 \%$ apresentaram conformidade com os padrões legais vigentes.

O procedimento para obter o selo de inspeção federal no Ministério da Agricultura Pecuária e Abastecimento é o seguinte:

Todos os estabelecimentos que queiram realizar comércio interestadual ou internacional de produtos de origem animal deverão buscar registro no DIPOA. Ao efetivarem o cadastro no DIPOA recebem o registro no Serviço de Inspeção Federal (SIF) ou o Título de Estabelecimento Relacionado (ER). Para obtenção do Registro ou Título de Relacionamento a localização, a construção e a qualidade da água a ser utilizada na indústria são avaliadas pelos Médicos Veterinários Fiscais Federais Agropecuários que atuam no DIPOA. O objetivo é evitar a construção de estabelecimentos não adequados à manipulação de alimentos pois, para esta atividade é extremamente importante o fluxo das operações e condições de ambiente visando minimizar, ao máximo, o risco de contaminação dos alimentos. Os estabelecimentos, registrados ou relacionados, devem manter seus dados cadastrais em dia, devendo o DIPOA ser comunicado de quaisquer alterações. Desta forma, projetos de reformas e alterações da estrutura da planta também devem ser encaminhados para análise prévia ${ }^{22}$.

É dever do Poder Público, por meio do Ministério da Agricultura Pecuária e Abastecimento atuar de forma efetiva na fiscalização da atividade, em prol da qualidade ambiental e da saúde coletiva ${ }^{23}: " 0$ Serviço de Inspeção Federal atua junto a cada estabelecimento, exigindo as boas práticas de fabricação e examinando os animais, antes e após a sua morte, descartando quaisquer produtos que sejam considerados impróprios para consumo".

Contudo, além dos riscos ambientais a saúde coletiva no mercado de consumo, o presente trabalho identifica, por outro lado, os riscos ambientais a quem labora no abate e processamento de carnes e derivados, passando a expor a seguir e de forma sistêmica, as normativas relacionadas a prevenção ambiental da saúde dos trabalhadores no seu ambiente laboral.

\footnotetext{
${ }^{21}$ Apud. MAPA, 2015

${ }^{22}$ Apud. MAPA, 2015.

${ }^{23}$ Apud. MAPA, 2015.
} 


\section{OS RISCOS AO AMBIENTE LABORAL E A SAÚDE DOS TRABALHADORES}

Os riscos ambientais da indústria de abate e processamento de derivados são indiscutíveis no que se refere a saúde coletiva, contudo, a primeira coletividade a sofrer os riscos ambientais desta atividade é o trabalhador que está exposto aos resíduos contaminantes em seu ambiente laboral. Destaca-se que o meio ambiente do trabalho é o local em que o trabalhador exerce o seu labor 8 horas por dia, considerando o que preceitua o artigo $7^{\circ}$, inciso XIII da Carta Magna brasileira de $1988^{24}$.

Para Rodolfo de Camargo Mancuso, o meio ambiente do trabalho é:

o habitat laboral, isto é, tudo que envolve e condiciona, direta ou indiretamente, o local onde o homem obtém os meios para prover o quanto necessário para a sua sobrevivência e desenvolvimento, em equilíbrio com o ecossistema ${ }^{25}$.

Por sua vez , preconiza neste sentido, Norma Sueli Padilha que : "O meio ambiente do trabalho compreenderia, assim, a inter-relação da força do trabalho humano (energia) e sua atividade no plano econômico através da produção (matéria), afetando o seu meio (ecossistema)" 26 .

A abrangência do ambiente laboral inclui o espaço interno e externo da empresa relacionado a todos os aspectos ocupacionais que estejam interligados à função que o trabalhador exerce no cotidiano.

Neste sentido, Norma Sueli Padilha esclarece que "quando aquele habitat se revele inidôneo a assegurar as condições mínimas para uma razoável qualidade de vida do trabalhador, aí se terá uma lesão ao meio ambiente do trabalho" ${ }^{27}$.

0 equilíbrio do meio ambiente do trabalho encontra fundamento no texto constitucional, por meio do artigo 225 e art. 200, inc. VIII, portanto o "habitat laboral" trata-se

\footnotetext{
${ }^{24}$ BRASIL. Constituição Federal. Brasília: Senado Federal, 1988. Artigo $7^{\circ}$, inciso XIII - duração do trabalho normal não superior a oito horas diárias e quarenta e quatro semanais, facultada a compensação de horários e a redução da jornada, mediante acordo ou convenção coletiva de trabalho; Disponível em: <http://www.planalto.gov.br/ccivil_03/Constituicao/Constituiçao.htm> Acesso em: 13 jul. 2015.

${ }^{25}$ MANCUSO, Rodolfo de Camargo. Ação civil pública trabalhista: análise de alguns pontos controvertidos. In Revista do Processo. São Paulo: Revista dos Tribunais, ano 24, n. 93, p.151-178, jan./mar. 1999.

${ }^{26}$ PADILHA, Norma Sueli. Fundamentos constitucionais do Direito Ambiental brasileiro. p. 377.

27 PADILHA, Norma Sueli. Do meio ambiente do trabalho equilibrado. São Paulo: Editora LTr, 2002. p. 39.
} 
de um direito fundamental do ser humano trabalhador e para o legislador constitucional uma de suas interfaces é a saúde pública.

Os direitos humanos a vida, ao trabalho, a saúde e ao meio ambiente humano é caracterizador da proteção jurídica da saúde do trabalhador.

Neste sentido, Sebastião Geraldo de Oliveira afirma que:

o primeiro e fundamental direito do ser humano, consagrado em todas as declarações internacionais é o direito à vida, suporte necessário par ao gozo dos demais direitos. Entretanto, não basta declarar o direito à vida sem assegurar os seus pilares básicos de sustentação: o trabalho e a saúde. Seria o mesmo que proclamar solenemente o direito à vida, mas não garantir o direito de viver ${ }^{28}$.

Segundo Lilliani alodi Rossit, "considerando que se trata de direitos de todos e essencial à sadia qualidade de vida, pode-se identificar a saúde, sem receio de errar como bem ambiental"29.

Assevera Norma Sueli Padilha que:

O meio ambiente do trabalho deve garantir o exercício da atividade produtiva do indivíduo, não considerado como máquina produtora de bens e serviços, mas, sim, como ser humano ao qual são asseguradas bases dignas para manutenção de uma sadia qualidade de vida ${ }^{30}$.

Com a reforma do Capítulo V do título II da CLT, artigos 154 a 201, datada do ano de 1977, por meio da Lei $n^{\circ} 6.514 / 77^{31}$, a prevenção à saúde no meio ambiente do trabalho foi adotada de forma técnica e mais abrangente.

O direito ambiental do trabalho sedimentou-se como um direito fundamental e do meio ambiente humano, na conjugação do artigo $7^{\circ}$ inciso XXII combinado com o artigo 225 da Constituição Federal de 1988, estabelecendo o meio ambiente do trabalho equilibrado, como um direito fundamental a prevenção aos riscos à segurança e saúde do trabalhador.

Quanto à regulamentação da prevenção aos riscos ambientais do trabalho é de competência do Ministério do Trabalho e Emprego, por meio das Normas Regulamentadoras,

${ }^{28}$ OLIVEIRA. Sebastião Geraldo de. Proteção Jurídica á Saúde do Trabalhador. $6^{\text {a }}$ edição;. São Paulo: LTR. 2011, p.106.

${ }^{29}$ ROSSIT, Liliana Allodi. 0 meio ambiente do Trabalho no direito ambiental brasileiro. São Paulo: Editora LTr, 2001, p. 93.

${ }^{30}$ PADILHA, Norma Sueli. O Equilíbrio do Meio ambiente do Trabalho: Direito Fundamental do Trabalhador e de Espaço Interdisciplinar entre o Direito do Trabalho e o Direito Ambiental. Rev. TST, Brasília, vol. 77, $\mathrm{n}^{\circ} 4$, out/dez/2011, p. 243.

${ }^{31}$ BRASIL. Lei n 6.514/77. Altera o Capítulo V do Titulo II da Consolidação das Leis do Trabalho, relativo a segurança e medicina do trabalho e dá outras providências. Artigos 154 a 201. In: Diário Oficial da República Federativa do Brasil, Brasília, DF, 23 dez. 1977. Disponível em: <http://www.planalto.gov.br/Ccivil_03/LEIS/L6514.htm> Acesso em: 13 jul. 2015. 
ISSN 1981-3694

(DOI): $10.5902 / 1981369418921$

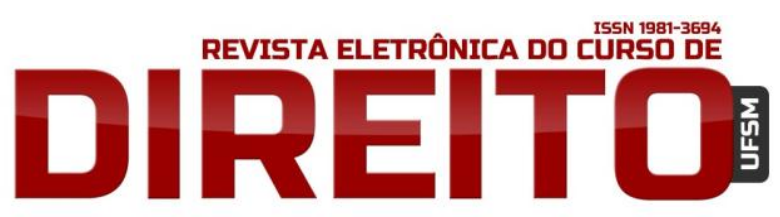

A PREVENÇÃO DOS RISCOS AMBIENTAIS PROVENIENTES DO ABATE E PROCESSAMENTO DE CARNES E DERIVADOS: A SAÚDE COLETIVA E DOS TRABALHADORES

GustaVo ABRAHÃO dOS SANTOS, NORMA SUELI PADILHA

legislar de forma específica e técnica, regulamentando a prevenção dos riscos ambientais do trabalho. As Normas Regulamentadoras são disposições complementares que objetiva regular de forma técnica as condições de prevenção a segurança e saúde do trabalhador, como as atividades econômicas com abate e processamento de carnes e derivados.

E como bem ambiental, a sadia qualidade de vida no ambiente laboral é uma relevante questão a ser contextualizada nos abatedouros de animais.

No abate e processamento de carnes e derivados existem riscos ambientais que expõem diretamente os trabalhadores a riscos ambientais, físicos, químicos e biológicos, exigindo a aplicação de instrumentos de prevenção da saúde de forma criteriosa e específica.

No ano de 2013, surge a Norma Regulamentadora - NR n 36 do Ministério do Trabalho e Emprego $^{32}$, com o intuito de regular a prevenção a segurança e saúde dos trabalhadores no meio ambiente do trabalho das empresas de abate e processamento de carnes e derivados.

Antes do advento da Norma Regulamentadora - NR $n^{\circ} 36$, o setor contava apenas com uma Nota Técnica 03/2004, elaborada pelo Departamento de Segurança e Saúde no Trabalho ${ }^{33}$, com valor de recomendação de boas práticas a serem adotadas pelas empresas na concepção e funcionamento do trabalho para preservar a saúde dos empregados. Esta Nota técnica, também fornecia subsídios aos auditores fiscais para a implementação de ações nas diversas modalidades do segmento, considerando a relevância e a complexidade dos fatores de risco presentes na atividade de abate e processamento de carnes e derivados.

Segundo Giovanni Moraes:

Conhecida como NR dos frigoríficos, a NR 36 busca a prevenção e a redução de acidentes de trabalho e doenças ocupacionais, com adequação e organização de postos de trabalho, adoção de pausas, gerenciamento de risco, disponibilização de Equipamentos de Proteção Individual (EPI) adequados, rodízios e atividades, entre outras ${ }^{34}$.

Frisa-se que, o meio ambiente de trabalho no abate e processamento de carnes e derivados, confere riscos a saúde do trabalhador, tanto de ordem psíquica, quanto ergonômica.

32 BRASIL. Ministério do Trabalho e Emprego. Norma Regulamentadora n. 36 do Ministério do Trabalho e Emprego. Trata da Segurança e saúde no trabalho em empresas de abate e processamento de carnes e derivados. In: Diário Oficial da República Federativa do Brasil, Brasília, DF, 19 abr 2013. Disponível em: http://portal.mte.gov.br/data/files/8A7C812D3DCADFC3013E237DCD6635C2/NR-

36\%20(atualizada\%202013).pdf Acesso em 13 jul 2015.

33 BRASIL. Nota técnica $\mathrm{n}^{\circ}$ 03/2004: refrigeração industrial por amônia : riscos, segurança e auditoria fiscal. - Brasília: MTE, SIT, DSST, 2005. 31 p. Disponível em: < http://portal.mte.gov.br/data/files/FF8080812BCB2790012BD580E60A0282/pub_cne_refrigeracao.pdf> Acesso em 14 jul. 2015.

${ }^{34}$ MORAES, Giovanni. Normas Regulamentadoras Comentadas e Ilustradas. Legislação de Segurança do Trabalho. Nova NR 36 comentada. Rio de Janeiro: GVC Editora, 2013, p.13. 
ISSN 1981-3694

(DOI): $10.5902 / 1981369418921$

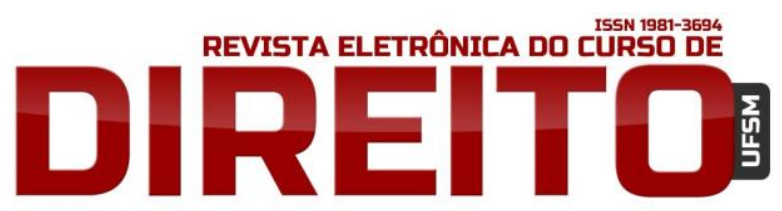

A PREVENÇ̃̃O DOS RISCOS AMBIENTAIS PROVENIENTES DO ABATE E PROCESSAMENTO DE CARNES E DERIVADOS: A SAÚDE COLETIVA

E DOS TRABALHADORES

GustaVo ABRAHÃO dOS SANTOS, NORMA SUELI PADILHA

Neste ponto, o número de animais abatidos e os movimentos repetitivos são riscos ambientais ergonômicos, e assim, a Norma Regulamentadora 36 do Ministério do Trabalho e Emprego, dispõe em seu texto sobre postos de trabalho e mobiliários, configurando-se a prevenção ergonômica do trabalhador, quando regula a análise ergonômica do trabalho.

Mas são os riscos insalubres presentes no meio ambiente de trabalho com abate e processamento de carnes e derivados, objeto de maior análise neste estudo do direito ambiental do trabalho. Frisa-se que a salubridade é o meio ambiente do trabalho favorável a saúde, logo a insalubridade é a falta de salubridade, motivada pelos riscos ambientais nocivos a saúde do trabalhador, sendo estes: riscos físicos, químicos e biológicos.

Segundo a Norma Regulamentadora $\mathrm{n}^{\circ} 15$ do Ministério do Trabalho e Emprego ${ }^{35}$, a insalubridade possui riscos ambientais, sendo eles: físicos, provenientes de ruído, calor, radiações, frio, pressões hiperbáricas, vibrações e umidade; químicos, oriundos de poeiras, gases, vapores, névoas e fumos; e biológicos, sendo os microorganismos, vírus e bactérias.

Neste passo, salienta-se que no abate e processamento de carnes e derivados existem os riscos ambientais físicos, sendo eles, a exposição ao frio e ruídos, riscos químicos na exposição à amônia nos frigoríficos, bem como os riscos ambientais biológicos, tais como, microorganismos, vírus e bactérias.

Dentro deste contexto, necessário se torna o conhecimento das condições ambientais de trabalho inerentes aos riscos insalubres e as medidas de prevenção a este meio ambiente do trabalho.

Frisa-se, portanto, a importância da Norma Regulamentadora (NR) $n^{\circ} 36$ do Ministério do Trabalho e Emprego - MTE, em que ressalta as condições ambientais do trabalho com abate e processamento de carnes e derivados, bem como estabelecendo em seu texto a prevenção ambiental do trabalhador a ruídos, conforto térmico, e ainda, prevenção aos riscos ambientais químicos e biológicos.

\footnotetext{
${ }^{35}$ BRASIL. Ministério do Trabalho e Emprego. Norma Regulamentadora n. 15 do Ministério do Trabalho e Emprego. Trata das atividades e operações insalubres In: Diário Oficial da República Federativa do Brasil, Brasília, DF, 06 jul $1978 . \quad$ Disponível <http://portal.mte.gov.br/data/files/8A7C816A47594D040147D14EAE840951/NR15\%20(atualizada\%202014).pdf>. Acesso em: 13 jul 2015.
} 
ISSN 1981-3694

(DOI): $10.5902 / 1981369418921$

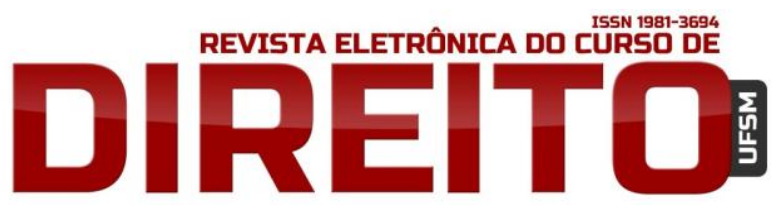

A PREVENÇ̃̃O DOS RISCOS AMBIENTAIS PROVENIENTES DO ABATE

E PROCESSAMENTO DE CARNES E DERIVADOS: A SAÚDE COLETIVA

E DOS TRABALHADORES

GustaVo ABRAHÃO dOS SANTOS, NORMA SUELI PADILHA

0 agente físico ruído, segundo Giovanni Moraes, "é uma das formas de energia que podem estar presente ou serem geradas no meio ambiente do trabalho de abate de animais e derivados" 36 .

O ruído como uma das formas de energia pode causar impacto ambiental na comunidade local, bem como danos à saúde de trabalhadores no abate e processamento de carnes e derivado, em face do movimento de máquinas e equipamentos nas operações de corte e processamento.

No entender de Giovanni Moraes, quanto aos impactos ambientais das principais fontes de ruído nos frigoríficos são:

Setores de recebimento e expedição: movimentação de veículos; operações de corte com serras elétricas; operações de produção de frio (refrigeração) compressores; operação de produção de vapor (setor de caldeiras); operação de concentração de proteínas/caldos em evaporadores múltiplo efeito ${ }^{37}$.

A NR 36 do MTE trata das condições ambientais do trabalho no item $36.9^{38}$, considerando que para o agente ruído deve existir controle a sua exposição, estabelecendo procedimentos que objetivem a eliminação ou redução dos ruídos e prevaleça a saúde laboral.

Neste sentido, assevera-se como meio de prevenção à saúde do trabalhador frente aos ruídos, organiza-se o espaço ambiental do trabalho com equipamentos de proteção coletiva e não sendo suficiente, conforme se determina a Norma Regulamentadora $n^{0} 6$ do Ministério do Trabalho e Emprego, necessário o uso do equipamento de proteção individual, aplicando treinamentos para a utilização dos protetores auriculares individuais. Outra medida de tutela a saúde dos trabalhadores neste caso, é a realização de exames médicos periódicos específicos nos trabalhadores seguindo-se a Norma Regulamentadora $n^{\circ} 7$ do Ministério do Trabalho e Emprego,

\footnotetext{
${ }^{36}$ MORAES, Giovanni. Op. Cit, p. 46.

${ }^{37}$ MORAES, Giovanni. Op. Cit, p. 46.

${ }^{38}$ BRASIL. Ministério do Trabalho e Emprego. Norma Regulamentadora n. 36 do Ministério do Trabalho e Emprego. Item 36.9.1.1 Para controlar a exposição ao ruído ambiental devem ser adotadas medidas que priorizem a sua eliminação, a redução da sua emissão e a redução da exposição dos trabalhadores, nesta ordem. Item 36.9.1.2 Todas as condições de trabalho com níveis de ruído excessivo devem ser objeto de estudo para determinar as mudanças estruturais necessárias nos equipamentos e no modo de produção, a fim de eliminar ou reduzir os níveis de ruído. Item 36.9.1.3 As recomendações para adequações e melhorias devem ser expressas em programas claros e objetivos, com definição de datas de implantação. Item 36.9.1.4 Caso não seja possível tecnicamente eliminar ou reduzir a emissão do ruído ou quando as medidas de proteção adotadas não forem suficientes ou encontrarem-se em fase de estudo, planejamento ou implantação, ou ainda em caráter complementar ou emergencial, devem ser adotadas medidas para redução da exposição dos trabalhadores obedecendo à seguinte hierarquia: a) medidas de caráter administrativo ou de organização do trabalho; b) utilização de equipamento de proteção individual - EPI.
} 
ISSN 1981-3694

(DOI): $10.5902 / 1981369418921$

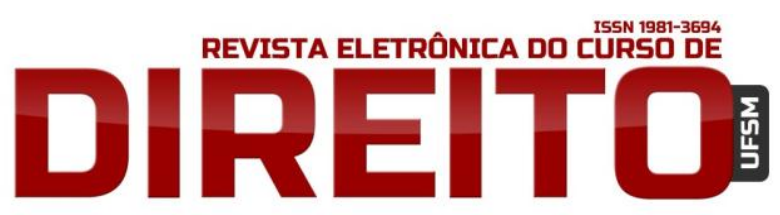

A PREVENÇ̃̃O DOS RISCOS AMBIENTAIS PROVENIENTES DO ABATE E PROCESSAMENTO DE CARNES E DERIVADOS: A SAÚDE COLETIVA

E DOS TRABALHADORES

GustaVo ABRAHÃO dOS SANTOS, NORMA SUELI PADILHA

estabelecido no programa de prevenção aos riscos ambientais, previsto na Norma Regulamentadora $\mathrm{n}^{\circ} 9$ do Ministério do trabalho e emprego.

No que tange aos riscos físicos oriundos do conforto térmico, ressalta-se medida de tutela a saúde dos trabalhadores, tanto para o frio quanto para o calor.

Neste sentido, afirma Giovanni Moraes que, “uma das reações naturais do corpo humano a baixas temperaturas é a contração dos músculos. (...) 0 frio constante também causa impactos no aparelho respiratório e facilita o aparecimento de doenças como sinusite e pneumonia” ${ }^{39}$.

Ressalta-se que o artigo $253 \mathrm{da} \mathrm{CLT}^{40}$, por exemplo, preconiza a realização de intervalos de 20 minutos a cada 1 hora e 40 minutos de exposição ao frio.

Neste sentido, a Norma Regulamentadora $n^{\circ} 36$ do MTE preconiza sobre o conforto térmico dos trabalhadores em abatedouros e indústria de processamento de carnes, determinando-se no item 36.9.5:

Devem ser adotadas medidas preventivas individuais e coletivas - técnicas, organizacionais e administrativas, em razão da exposição em ambientes artificialmente refrigerados e ao calor excessivo, para propiciar conforto térmico aos trabalhadores. ${ }^{41}$

E assim, no entender de Giovanni Moraes:

O problema é que as empresas nem sempre cumprem essa determinação, priorizando a alta produtividade e o lucro. Elas questionam que essa pausa só vale para os trabalhadores dos setores com temperaturas negativas, onde as carnes ficam congeladas. Porém o Mistério Público do Trabalho (MPT) entende que o intervalo de 20 minutos deve ser estendido a qualquer trabalhador de ambiente 'artificialmente frio'. É o caso daqueles que ficam nas salas de desossa de animais, onde as temperaturas são positivas, mas nunca ultrapassam os $15^{\circ}$ $\mathrm{C}^{42}$.

Sendo este o entendimento da Súmula 438 do Tribunal Superior do Trabalho:

INTERVALO PARA RECUPERAÇÃO TÉRMICA DO EMPREGADO. AMBIENTE ARTIFICIALMENTE FRIO. HORAS EXTRAS. ART. 253 DA CLT. APLICAÇÃO ANALÓGICA

- Res. 185/2012, DEJT divulgado em 25, 26 e 27.09.2012 . O empregado submetido a trabalho contínuo em ambiente artificialmente frio, nos termos do

\footnotetext{
${ }^{39}$ MORAES, Giovanni, Op. Cit. , p. 65.

40 BRASIL. Decreto 5452/43. Aprova a Consolidação das Leis do Trabalho. In: Dia' rio Oficial da União, Brasília, DF, 09 ago. 1943. Disponível em: <http://www.planalto.gov.br/ccivil_03/decretolei/Del5452.htm> Acesso em 15 jul. 2015.

${ }^{41}$ BRASIL. Ministério do Trabalho e Emprego. Norma Regulamentadora n. 36 do Ministério do Trabalho e Emprego.

${ }^{42}$ MORAES, Giovanni, Op. Cit., p. 65.
} 
parágrafo único do art. 253 da CLT, ainda que não labore em câmara frigorífica, tem direito ao intervalo intrajornada previsto no caput do art. $253 \mathrm{da}$ $\mathrm{CLT}^{43}$.

A Norma Regulamentadora $\mathrm{n}^{\circ} 36$ do MTE resta clara e expressa no item 36.9.5.1.1, quanto às medidas de prevenção relacionadas ao conforto térmico, preconizando-se no mínimo:

a) controle da temperatura, da velocidade do ar e da umidade; b) manutenção constante dos equipamentos; c) acesso fácil e irrestrito a água fresca; d) uso de EPI e vestimenta de trabalho compatível com a temperatura do local e da atividade desenvolvida; e) outras medidas de proteção visando o conforto térmico ${ }^{44}$.

Relata Giovanni Moraes que:

o Ministério Público do Trabalho vem fazendo acordos com frigoríficos de todo o país para melhorar as condições de trabalho, como previsto no artigo 253 da CLT. Quando o acordo não é possível, o MPT tem acionado a Justiça do Trabalho para que as empresas cumpram a lei ${ }^{45}$.

Frisa-se neste sentido, menciona-se o acordo judicial entre o Ministério Público do Trabalho e a empresa JBS S.A (Friboi) no processo $n^{\circ}$ 0001751-64.2011.5.15.0011 na comarca de Barretos $/ \mathrm{SP}^{46}$.

\footnotetext{
${ }^{43}$ BRASIL. Tribunal Superior do Trabalho. Súmula $\mathrm{n}^{\circ} 438$. Disponível em: <http://www3.tst.jus.br/jurisprudencia/Sumulas_com_indice/Sumulas_Ind_401_450.html\#SUM-438>. Acesso em: 14 jul. 2015.

${ }^{44}$ BRASIL. Ministério do Trabalho e Emprego. Norma Regulamentadora n. 36 do Ministério do Trabalho e Emprego.

${ }^{45}$ MORAES, Giovanni, Op. Cit., p. 65.

${ }^{46}$ Segundo o sítio eletrônico da $15^{\mathrm{a}}$ Região do Ministério Público do Trabalho: “Um acordo judicial firmado entre Ministério Público do Trabalho e frigorífico JBS S.A (Friboi) beneficiará trabalhadores da unidade da empresa em Barretos, interior de São Paulo. Cada funcionário que trabalha em câmara frigorífica ou local artificialmente refrigerado terá o direito de receber R\$ 100 para cada mês trabalhado, no período de novembro de 2009 a dezembro de 2011. Além disso, o frigorífico pagará uma indenização por danos morais coletivos no importe de R\$130 mil. O acordo, homologado pela Vara do Trabalho de Barretos, encerra a ação civil pública ajuizada pelo MPT contra o frigorífico pela não concessão dos intervalos para recuperação térmica aos funcionários que trabalham em ambientes frios (até $12{ }^{\circ} \mathrm{C}$ ), previstos em lei. A ação atinge os empregados da unidade de Barretos (SP). A relação com nomes e quantidade de beneficiários deve ser entregue pelo JBS à Justiça, contendo também o montante que cada um receberá e os cálculos da incidência desses valores nos benefícios previdenciários. 0 MPT se apoiou no artigo 253 da CLT (Consolidação das Leis do Trabalho), que prevê paradas de 20 minutos a cada $1 \mathrm{~h} 40 \mathrm{~min}$ trabalhadas dentro de câmaras frigoríficas. A aplicação da lei em relação a empregados que trabalham em ambientes artificialmente frios sempre foi necessária, mas se consolidou em 2012, com o Enunciado $n^{\circ} 438$, editado pelo Tribunal Superior do Trabalho ${ }^{46}$."
} 
ISSN 1981-3694

(DOI): $10.5902 / 1981369418921$

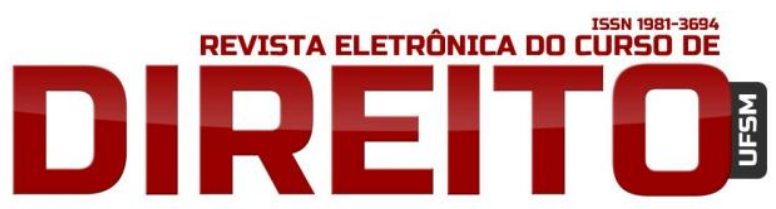

A PREVENÇ̃̃O DOS RISCOS AMBIENTAIS PROVENIENTES DO ABATE E PROCESSAMENTO DE CARNES E DERIVADOS: A SAÚDE COLETIVA

E DOS TRABALHADORES

GustaVo ABRAHÃO dOS SANTOS, NORMA SUELI PADILHA

Por outro lado, no abate e processamento de carnes e derivados existe os riscos ambientais químicos, advindos da amônia em sistemas de refrigeração fechado como é o caso no abate e processamento de carnes e derivados.

Segundo Giovanni Moraes: “a amônia é um gás tóxico que inalado possui inúmeros prejuízos a saúde humana" ${ }^{47}$.

Como medida de proteção a saúde do trabalhador quanto aos riscos químicos e em particular a amônia, deve se respeitar a Norma Regulamentadora 36 do Ministério do Trabalho e Emprego, no item 36.9.3 e seus subitens respectivos ${ }^{48}$.

E também devem ser utilizados para a prevenção ambiental do trabalhador, os equipamentos de proteção individual adequados ao risco ocupacional, atendendo a Norma Regulamentadora $n^{\circ} 6$ do Ministério do Trabalho e Emprego.

Existe também a exposição de trabalhadores a outros riscos ambientais químicos advindos dos procedimentos de limpeza e sanitários, por meio de detergentes e outros produtos auxiliares.

No que se refere, em específico, ao risco ambiental químico ao trabalhador, segundo Giovanni Moraes:

na industrialização das carnes, pode-se fazer uso de sais e de outras substâncias dos tipos de produtos em processos. Cloreto, nitrato e nitrito de sódio, ascorbatos, caseinatos, glutamatos e polifosfatos podem ser utilizados para aplicação nas carnes por meio de soluções (via injeções ou imersões) ou podem ser aplicados em processos de salga ou cura a seco ${ }^{49}$.

\footnotetext{
${ }^{47}$ MORAES, Giovanni. Op. Cit. p. 52.

${ }^{48}$ BRASIL. Ministério do Trabalho e Emprego. Norma Regulamentadora n. 36 do Ministério do Trabalho e Emprego. Subitem. 36.9.3.1 A empresa deve adotar medidas de prevenção coletivas e individuais quando da utilização de produtos químicos. Subitem 36.9.3.2 As medidas de prevenção coletivas a serem adotadas quando da utilização de amônia devem envolver, no mínimo: a) manutenção das concentrações ambientais aos níveis mais baixos possíveis e sempre abaixo do nível de ação (NR-09), por meio de ventilação adequada; b) implantação de mecanismos para a detecção precoce de vazamentos nos pontos críticos, acoplados a sistema de alarme; c) instalação de painel de controle do sistema de refrigeração; d) instalação de chuveiros de segurança e lava-olhos; e) manutenção de saídas de emergência desobstruídas e adequadamente sinalizadas; f) manutenção de sistemas apropriados de prevenção e combate a incêndios, em perfeito estado de funcionamento; g) instalação de chuveiros ou sprinklers acima dos grandes vasos de amônia, para mantê-los resfriados em caso de fogo, de acordo com a análise de risco; $h$ ) manutenção das instalações elétricas à prova de explosão, próximas aos tanques; i) sinalização e identificação dos componentes, inclusive as tubulações; $j$ ) permanência apenas das pessoas autorizadas para realizar atividades de inspeção, manutenção ou operação de equipamentos na sala de máquinas. Subitem 36.9.3.2.1 Em caso de vazamento de amônia, o painel de controle do sistema de refrigeração deve: a) acionar automaticamente o sistema de alarme; b) acionar o sistema de controle e eliminação da amônia.

${ }^{49}$ MORAES, Giovanni. Op. Cit. p. 61.
} 
ISSN 1981-3694

(DOI): $10.5902 / 1981369418921$

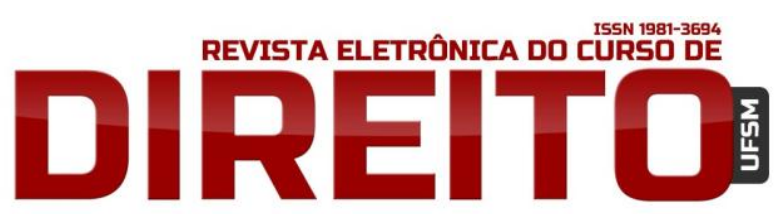

A PREVENÇÃO DOS RISCOS AMBIENTAIS PROVENIENTES DO ABATE E PROCESSAMENTO DE CARNES E DERIVADOS: A SAÚDE COLETIVA

E DOS TRABALHADORES

GustaVo ABRAHÃO dOS SANTOS, NORMA SUELI PADILHA

Por sua vez há ainda os riscos ambientais biológicos no processo de abate dos animais e processamento das carnes e derivados, sendo necessário, como medida coletiva a aplicação da Norma Regulamentadora $\mathrm{n}^{\circ} 24$ do Ministério do Trabalho e Emprego, que trata das condições sanitárias e conforto nos locais de trabalho, e imprescindível, a higiene pessoal, os equipamentos de proteção individual e os exames médicos determinados no programa de controle da saúde ocupacional, pois existe nesta atividade, contato com microorganismos, bactérias e vírus nos processos de abate de animais.

Em específico, a Norma Regulamentadora $n^{\circ} 36$ do MTE preconiza no item 36.9.4 e seus subitens $^{50}$, as questões de segurança e saúde do trabalhador atreladas ao cotidiano laboral nesta atividade econômica.

Contudo, todos os riscos ambientais insalubres condicionam os trabalhadores a receberem a monetização do risco ocupacional por meio de um adicional de insalubridade, advindo pela exposição ao risco ambiental, seja ele por exposição a agentes físicos, químicos ou biológicos.

Todavia o percentual de 10, 20 ou 40\% sobre o salário mínimo, como preceitua o artigo 192 da Consolidação das Leis Trabalhistas, não compensa os danos à saúde dos trabalhadores, muito menos toda poluição advinda do labor ambiental, no que se refere ao abate e processamento de carnes e derivados, principalmente, quando os empregadores desta atividade econômica, não cumprem com as normas regulamentadoras deste direito ambiental do trabalho.

Afirma Norma Sueli Padilha que:

A ocorrência, por exemplo, de acidente de trabalho, ou de qualquer afetação da saúde do trabalhador, quer no contexto individual ou no coletivo, causados pela degradação do meio ambiente do trabalho e poluição labor-ambiental, atraem a eficácia irradiante de um direito fundamental, o equilíbrio do meio ambiente do trabalho, portanto, amplia-se a tutela para além do direito do trabalho, pois se

\footnotetext{
${ }^{50}$ BRASIL. Ministério do Trabalho e Emprego. Norma Regulamentadora n. 36 do Ministério do Trabalho e Emprego. Subitem 36.9.4.1 Devem ser identificadas as atividades e especificadas as tarefas suscetíveis de expor os trabalhadores a contaminação biológica, através de: a) estudo do local de trabalho, considerando as medidas de controle e higiene estabelecidas pelas Boas Práticas de Fabricação - BPF; b) controles mitigadores estabelecidos pelos serviços de inspeção sanitária, desde a criação até o abate; c) identificação dos agentes patogênicos e meios de transmissão; d) dados epidemiológicos referentes ao agente identificado, incluindo aqueles constantes dos registros dos serviços de inspeção sanitária; e) acompanhamento de quadro clínico ou subclínico dos trabalhadores, conforme Programa de Controle Médico de Saúde Ocupacional - PCMSO. Subitem 36.9.4.2 Caso seja identificada exposição a agente biológico prejudicial à saúde do trabalhador, conforme item anterior, deverá ser efetuado o controle destes riscos, utilizando-se, no mínimo, das seguintes medidas: a) procedimentos de limpeza e desinfecção; b) medidas de biossegurança envolvendo a cadeia produtiva; c) medidas adotadas no processo produtivo pela própria empresa; d) fornecimento de equipamentos de proteção individual adequados; e) treinamento e informação aos trabalhadores.
} 
ISSN 1981-3694

(DOI): $10.5902 / 1981369418921$

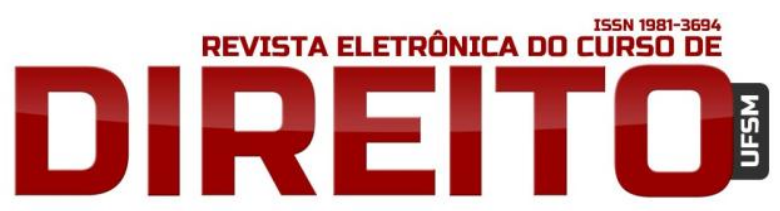

A PREVENÇ̃̃O DOS RISCOS AMBIENTAIS PROVENIENTES DO ABATE E PROCESSAMENTO DE CARNES E DERIVADOS: A SAÚDE COLETIVA

E DOS TRABALHADORES

GustaVo ABRAHÃO dOS SANTOS, NORMA SUELI PADILHA

trata de dano ambiental, que impõe a aplicação do regime sistemático do direito constitucional ambiental ${ }^{51}$.

Enfim, a tutela da saúde do trabalhador na indústria de abate e processamento de carnes, integra o direito constitucional ambiental previsto no artigo 225 da Carta Magna e os direitos fundamentais dos trabalhadores no artigo $7^{\circ}$ da Constituição Federal de 1988 , quanto a prevenção aos riscos ocupacionais. Considerando que os trabalhadores possuem um bem ambiental que deve ser tutelado com máxima efetividade, sendo este bem ambiental a saúde do trabalhador, os ditames estão contidos nos artigos 154 a 201, e ainda artigo 253, todos da Consolidação das Leis Trabalhistas, mas que possuem eficácia por meio da regulamentação específica, como é o caso da atual e comentada Norma Regulamentadora n. 36 do MTE, e ainda, a sua integração a proteção da saúde dos trabalhadores, conferidas pelas Normas Regulamentadoras n. 6, 7, 9, 15 e 24 do MTE.

\section{CONCLUSÃO}

A carne é um dos alimentos mais consumidos no Brasil, seja ela proveniente de abate de bovinos, ovinos e suínos, bem como possui um mercado de exportação em expansão, entretanto os riscos ambientais decorrentes do processo de abatedouros é bastante significativo e preocupante, tendo em vista as externalidades negativas resultantes dos resíduos sólidos e líquidos decorrentes da atividade, que possui grande impacto com relação ao meio ambiente, a saúde coletiva, e ao ambiente laboral.

Por tratar-se de uma atividade com alto risco de contaminação ambiental faz-se necessário a aplicação dos instrumentos da legislação ambiental, tais como o Estudo Prévio de Impacto Ambiental e o processo de licenciamento ambiental. A atuação efetiva e eficaz do poder de polícia dos órgãos da Administração Pública é essencial para o controle dos abatedouros de animais dado o alto risco de impacto para a qualidade ambiental.

A alta possibilidade de clandestinidade nesta atividade expõe a saúde pública a um risco perigoso de contaminação, o que potencializa a gravidade da falta de fiscalização por parte do

51 PADILHA, Norma Sueli. Meio Ambiente do Trabalho: Um direito fundamental do Trabalhador e a Superação da Monetização do Risco. Rev. TST, Brasília, vol 79, n 4, out/dez 2013, p. 178. 
ISSN 1981-3694

(DOI): $10.5902 / 1981369418921$

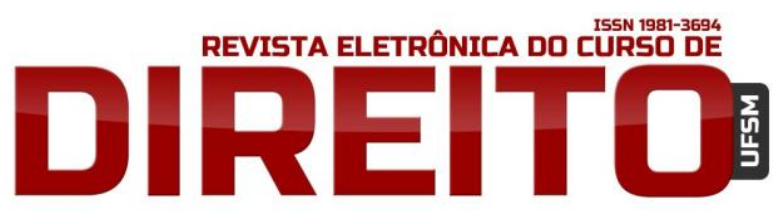

A PREVENÇ̃̃O DOS RISCOS AMBIENTAIS PROVENIENTES DO ABATE E PROCESSAMENTO DE CARNES E DERIVADOS: A SAÚDE COLETIVA

E DOS TRABALHADORES

GustaVo ABRAHÃO dOS SANTOS, NORMA SUELI PADILHA

Estado na exigência das licenças ambientais. A ineficiência na fiscalização expõe não só o meio ambiente, o consumidor, o bem estar animal, o trabalhador, mas também a viabilidade econômica da atividade, pois o mercado exportador possui exigências rígidas com relação ao controle de qualidade ambiental na produção das carnes e derivados.

Neste contexto, o licenciamento ambiental na indústria de abate e processamento de carnes e derivados, bem como o selo de inspeção federal e demais inspeções de órgãos competentes, são primordiais para assegurar a saúde coletiva.

As normas ambientais que preconizam o principio da prevenção e do poluidor pagador são garantidoras não apenas da qualidade ambiental em prol do meio ambiente, do consumidor, do bem estar animal, mas também do trabalhador.

Os trabalhadores que atuam na indústria do abate e processamento de carnes e derivados, expostos aos riscos da atividade, por força dos fundamentos constitucionais do direito ambiental tem garantido o seu direito fundamental a um ambiental laboral saudável. Frisa-se que, o surgimento da Norma Regulamentadora $n^{\circ} 36$ do MTE, é fruto da incidência do direito ambiental do trabalho e de seus princípios.

Neste passo, para se ter efetividade frente à prevenção dos riscos ambientais na indústria do abate é preciso que as empresas do setor se submetam as regras preventivas e assumam sua responsabilidade socioambiental. Bem como, cabe a Administração Pública atuar de forma eficaz por meio do poder de polícia dos órgãos vinculados ao Ministério da Agricultura, Pecuária e Abastecimento, bem como do poder de polícia dos órgãos do Ministério do Meio Ambiente e do próprio Ministério do Trabalho e Emprego, com vistas a zelar, tanto pela saúde pública, como pela saúde dos trabalhadores, sendo ambas circunscritas na sadia qualidade de vida.

Pode-se afirmar que o cumprimento das normas ambientais que preconizam o principio da prevenção e do poluidor pagador, e a responsabilidade socioambiental das empresa e se referem à prevenção de riscos ambientais nas atividades agroindustriais brasileiras, são garantidoras não apenas da qualidade ambiental em prol do meio ambiente, do consumidor, do trabalhador, mas de forma geral, são garantidoras da sustentabilidade, no sua total abrangência, ambiental, social e econômica. E, a sustentabilidade é o grande desafio que pode significar também vantagem competitiva, pois sustentar é integrar, e é preciso integrar ao preconizado sucesso da indústria da carne, a qualidade ambiental para a saúde do meio ambiente, dos consumidores, e do trabalhador, sem olvidar o bem estar animal. 


\section{REFERÊNCIAS}

ALENCAR, N. (2002) Abatedouros de Bovinos e suínos. CTP - Revista Tecnologia e Treinamento Agropecuário. Disponível em: <http://www.cpt.com.br/revista/mattec/0165.asp > Acesso em: 24 jun. 2014.

ANTUNES, Paulo de Bessa. Direito Ambiental. 11. ed. Rio de Janeiro: Lumen Juris Editora, 2008.

BANDEIRA DE MELLO, Oswaldo Aranha. Princípios gerais de direito administrativo. Rio de Janeiro. Forense, 1969, v.1, pág. 509.

BNB. BANCO DO NORDESTE. Manual de Impactos Ambientais. Coord. Ademir Costa 1. ed. .Fortaleza: Banco do Nordeste, 1999. 297p.

BRASIL. 15 ${ }^{\text {a }}$ Região do Ministério Público do Trabalho. Acordo judicial entre o Ministério Público do Trabalho e a empresa JBS S.A (Friboi) no processo ${ }^{\circ}$ 0001751-64.2011.5.15.0011 na comarca de Barretos/SP. Disponível em: <http://www.prt15.mpt.gov.br/2-uncategorised/256acordo-com-jbs-friboi-beneficia-diretamente-trabalhadores-de-barretos> Acesso em: 10 jul.2015.

BRASIL. Constituição Federal. Brasília: Senado Federal, 1988. Disponível em: <http://www.planalto.gov.br/ccivil_03/Constituicao/Constituiçao.htm> Acesso em: 13 jul. 2015.

BRASIL. Decreto 5452/43. Aprova a Consolidação das Leis do Trabalho. In: Diário Oficial da República Federativa do Brasil, Brasília, DF, 09 ago. 1943. Disponível em:

<http://www.planalto.gov.br/ccivil_03/decreto-lei/Del5452.htm> Acesso em 15 jul. 2015.

BRASIL. Lei n. 6.514/77. Altera o Capítulo V do Titulo II da Consolidação das Leis do Trabalho, relativo a segurança e medicina do trabalho e dá outras providências. In: Diário Oficial da República Federativa do Brasil, Brasília, DF, 23 dez. 1977. Disponível em:

<http://www.planalto.gov.br/Ccivil_03/LEIS/L6514.htm> Acesso em 13 jul. 2015.

BRASIL. Lei $n^{\circ} 7 ; 347$ de 1985. Disciplina a ação civil pública de responsabilidade por danos causados ao meio-ambiente, ao consumidor, a bens e direitos de valor artístico, estético, histórico, turístico e paisagístico (VETADO) e dá outras providências. In: Diário Oficial da República Federativa do Brasil, Brasília, DF, 25 jul. 1985. Disponível em: < http://www.planalto.gov.br/ccivil_03/leis/L7347orig.htm> Acesso em 13 jul.2015.

BRASIL. Ministério da Agricultura Pecuária e Abastecimento (MAPA). Decreto $n^{\circ} 30.691$ de 29/03/1952. Dispõe sobre o Regulamento da inspeção industrial e sanitária de produtos de origem anima e dá outras providências. In: Diário Oficial da República Federativa do Brasil, Brasília, DF, 7 jul. 1952. Disponível em: < http://www.planalto.gov.br/ccivil_03/decreto/19501969/D30691.htm> Acesso em 13 jul. 2015. 
BRASIL. Ministério da Agricultura, Pecuária e Abastecimento (MAPA). Disponível em: <http://www.agricultura.gov.br/animal/dipoa/dipoa-empresario/registro-estabelecimento>. Acesso em: 09 out.2015.

BRASIL. Ministério da Agricultura, Pecuária e Abastecimento (MAPA). Disponível em: <http://www.agricultura.gov.br/animal/noticias/2013/02/mapa-alerta-para-os-perigos-doconsumo-de-carne-sem-fiscalizacao> Acesso em: 09 out.2015.

BRASIL. Ministério do Trabalho e Emprego. Norma Regulamentadora n. 36 do Ministério do Trabalho e Emprego. Trata da Segurança e saúde no trabalho em empresas de abate e processamento de carnes e derivados. In: Diário Oficial da República Federativa do Brasil, Brasília, DF, 19 abr 2013. Disponível em :

<http://portal.mte.gov.br/data/files/8A7C812D3DCADFC3013E237DCD6635C2/NR-

36\%20(atualizada\%202013).pdf> Acesso em: 13 jul. 2015.

BRASIL. Ministério do Trabalho e Emprego. Norma Regulamentadora n. 15 do Ministério do Trabalho e Emprego. Trata das atividades e operações insalubres In: Diário Oficial da República Federativa do Brasil, Brasília, DF, 06 jul 1978. Disponível em:

<http://portal.mte.gov.br/data/files/8A7C816A47594D040147D14EAE840951/NR15\%20(atualizada\%202014).pdf> Acesso em: 13 jul 2015.

BRASIL. Nota técnica $n^{\circ}$ 03/2004: refrigeração industrial por amônia : riscos, segurança e auditoria fiscal. - Brasília : MTE, SIT, DSST, 2005. 31 p.Disponível em: <

http://portal.mte.gov.br/data/files/FF8080812BCB2790012BD580E60A0282/pub_cne_refrigeraca o.pdf> Acesso em: 14 jul. 2015.

BRASIL. Resolução CONAMA 385/06. Estabelece procedimentos a serem adotados para o licenciamento ambiental de agroindústrias de pequeno porte e baixo potencial de impacto ambiental. In: Diário Oficial da República Federativa do Brasil, Brasília, DF, 29 dez. 2006. Disponível em <http://www.mma.gov.br/port/conama/legiabre.cfm?codlegi=523> Acesso em: 13 jul. 2015.

BRASIL. Resolução do Conselho Nacional do Meio ambiente (CONAMA) 237/97. Dispõe sobre a revisão e complementação dos procedimentos e critérios utilizados para o licenciamento ambiental In: Diário Oficial da República Federativa do Brasil, Brasília, DF, 22 dez. 1997. Disponível em:

<http://www.mma.gov.br/port/conama/legislacao/CONAMA_RES_CONS_1997_237.pdf> Acesso em: 13 jul. 2015.

BRASIL. Tribunal Superior do Trabalho. Súmula 438. Disponível em: <http://www3.tst.jus.br/jurisprudencia/Sumulas_com_indice/Sumulas_Ind_401_450.html\#SUM438>. Acesso em: 14 jul. 2015.

CORDEIRO, Silvia. MP-PR pede interdição e fechamento do abatedouro de Ponta Grossa. Ação civil pública foi ajuizada contra município e administradora do local.

Matadouro está em "condições ambientais e sanitárias precárias", alega MP. G1, globo, Paraná. Disponível em: <http://g1.globo.com/pr/campos-gerais-sul/noticia/2013/10/mp-pr-pedeinterdicao-e-fechamento-do-abatedouro-de-ponta-grossa.html>Acesso em: 13 jul. 2015. 
DA SILVA, Solange Teles. Princípio da Precaução: Uma nova postura em face dos riscos e incertezas científicas. In VARELLA, Marcelo Dias e PLATIAU, Ana Flávia de Barros. Precaução ambiental. Belo Horizonte: Del Rey, 2004.

FIGUEIREDO, ACC. Eutanásia animal em centros de controle de zoonoses. Revista do Conselho Federal de Medicina Veterinária, 2001;23:12-7.

KRELL, Andreas Joachim.O licenciamento ambiental no SISNAMA: Competência e controle. Paisagem, Natureza e Direito. BENJAMIN, Anotnio Herman (Org.) São Paulo: Instituto O direito por um Planeta Verde,2005, Vol. 1, p. 167.

MANCUSO, Rodolfo de Camargo. Ação civil pública trabalhista:análise de alguns pontos controvertidos. In Revista do Processo. São Paulo: Revista dos Tribunais, ano 24, n. 93, p.151178, jan./mar. 1999.

MILARÉ, Edis. Direito do Ambiente : doutrina, pratica, jurisprudência, glossário 2. ed. rev. atual. e ampl. - São Paulo: Revista dos Tribunais,2001.

MORAES, Giovanni. Normas Regulamentadoras Comentadas e Ilustradas. Legislação de Segurança do Trabalho. Nova NR 36 comentada. Rio de Janeiro: GVC, 2013.

OLIVEIRA. Sebastião Geraldo de. Proteção Jurídica á Saúde do Trabalhador. $6^{a}$ ed., São Paulo: LTR. 2011.

PADILHA, Norma Sueli. Do meio ambiente do trabalho equilibrado. São Paulo: Editora LTr, 2002.

PADILHA, Norma Sueli. Fundamentos Constitucionais do Direito Ambiental Brasileiro, $1^{\mathrm{a}}$ ed. Elsevier, p. 37, 2010.

PADILHA, Norma Sueli. Meio Ambiente do Trabalho: Um direito fundamental do Trabalhador e a Superação da Monetização do Risco. Rev. TST, Brasília, vol 79, n 4, out/dez 2013, p. 173-182.

PADILHA, Norma Sueli. O Equilíbrio do Meio ambiente do Trabalho: Direito Fundamental do Trabalhador e de Espaço Interdisciplinar entre o Direito do Trabalho e o Direito Ambiental. Rev. TST, Brasília, vol. 77, n 4, out/dez/2011.

PARDI MC, Santos IF, Souza ER, Pardi HS. Ciência higiene e tecnologia da carne. Goiânia: EDUFF; 1993.

REVISTA NACIONAL DA CARNE. Disponível em: <http://nacionaldacarne.com.br/apos-novorecorde-exportacoes-de-bovino-miram-alta-de-11-em-2015/> Acesso em: 09 out. 2015.

ROCHA MARIA, R. Avaliação da eficiência no tratamento de efluentes líquidos em frigoríficos.In: Trabalho de Conclusão de Curso, apresentado à banca examinadora da Faculdade Dinâmica das Cataratas - UDC, como requisito parcial para obtenção de grau de Engenharia Ambiental. Prof. Orientador: Edneia Santos de Oliveira Lourenço. UDC. Foz do Iguaçu, 2008. 
ISSN 1981-3694

(DOI): $10.5902 / 1981369418921$

ROSSIT, Liliana Allodi. O meio ambiente do Trabalho no direito ambiental brasileiro. São Paulo: LTr, 2001.

ROUQUAYROL, Maria Zelia; ALMEIDA FILHO, Naomar de. Epidemiologia e saúde. 6.ed. Rio de Janeiro: Medsi, 2003., p. 499-513.

SEGRE, Marco and FERRAZ, Flávio Carvalho. O conceito de saúde. Rev.Saúde Pública. 1997, vol.31, n.5, pp. 538-542.

TRENNEPOHL, Terence Dornelles. Fundamentos de Direito Ambiental. 2a edição, Editora Podvim, 2007, p. 95.

Recebido em: 24.07.2015 / Revisado em 07.10.2015 / Aprovado em: 15.10.2015 